\title{
Combined effect of pollen quality and thiamethoxam on hypopharyngeal gland development and protein content in Apis mellifera
}

\author{
Maria Teresa Renzi ${ }^{1}$, Neus Rodríguez-Gasol ${ }^{1,2}$, Piotr Medrzycki ${ }^{3}$, Claudio PorrinI ${ }^{1}$, \\ Antonio MartinI ${ }^{1}$, Giovanni Burgio ${ }^{1}$, Stefano MainI ${ }^{1}$, Fabio SGOlastra ${ }^{1}$ \\ ${ }^{1}$ Department of Agricultural Sciences, University of Bologna, Viale Fanin 42, 40127, Bologna, Italy \\ ${ }^{2}$ IRTA, PCiTAL, Parc de Gardeny, Edifici Fruitcentre, 25003, Lleida, Spain \\ ${ }^{3}$ Honey Bee and Silkworm Research Unit, CREA-API, Council for Agricultural Research and Economics, Via di Saliceto \\ 80, 40128, Bologna, Italy
}

Received 30 September 2015 - Revised 12 January 2016 - Accepted 4 February 2016

\begin{abstract}
Pollen diet is essential to nurse bees to develop hypopharyngeal glands (HPGs) and produce royal jelly to feed larvae. The effect of different diet regimes combined with pesticide exposure on the development of HPGs in honeybees was studied. In particular, a high-quality pollen mixture (high pollen diversity and protein content) and a low-quality diet (low pollen diversity and protein content) were combined with the chronic administration of thiamethoxam $(10$ and $40 \mu \mathrm{g} / \mathrm{L})$. The impact of these stressors was evaluated by measuring the size of HPG acini and the total protein content of bee heads in 8- and 12-day-old bees. Bees fed with sub-lethal concentrations of thiamethoxam and with the low-quality diet exhibited smaller and irregularly shaped acini. The total protein content in bee head was also affected by pesticide administration, while the pollen quality did not cause significant modifications. In conclusion, these results highlighted the importance of the food quality, considered as nutritional value and pesticide contamination, for the physiological development of honeybees.
\end{abstract}

\section{HPGs / honeybee / neonicotinoid / pollen diet / chronic toxicity}

\section{INTRODUCTION}

The abundance and quality of pollen has been individuated as a relevant factor in influencing honeybee health not only at the individual level but also at the colony level (Brodschneider and Crailsheim 2010; Naug 2009). Pollen provides the only source of proteins which are needed to ensure a correct development and functioning of many organs and

Electronic supplementary material The online version of this article (doi:10.1007/s13592-016-0435-9) contains supplementary material, which is available to authorized users.

Corresponding author: F. Sgolastra, fabio.sgolastra2@unibo.it

Manuscript editor: Klaus Hartfelder tissues in honeybees (Haydak 1970). Protein content in pollen may vary considerably among plant species, ranging from 2.5 to $61 \%$ (Roulston and Cane 2000), with different patterns in amino acid profile (Auclair and Jamieson 1948). Pollen is essential for the production of royal jelly, a high-protein food used to feed bee larvae and adult queens (Crailsheim 1992). Royal jelly is secreted by two hypopharyngeal glands (HPGs), situated in the head, which reach maximum development in nurse bees, around 6-8 days after emergence, and afterwards degenerate in forager bees (Deseyn and Billen 2005). A decrease in availability and protein content of bee-collected pollen may result in the development of smaller HPGs (DeGrandi-Hoffman et al. 2010; Di Pasquale et al. 2013), less brood reared 
(DeGrandi-Hoffman et al. 2008; Herbert et al. 1977), shorter longevity (Di Pasquale et al. 2013; Schmidt et al. 1987) and recruitment of hive bees at a younger age (Sagili and Pankiw 2007), which ultimately entails a reduced lifespan (Khoury et al. 2011). Pollen also represents one of the most frequent ways of exposure to pesticides (Krupke et al. 2012; Mullin et al. 2010), particularly relevant for nurse bees and larvae, which consume the highest amount of stored pollen (Rortais et al. 2005). The residual concentrations of highly toxic pesticides, like neonicotinoids, are still able to induce adverse effects in bees, such as the lowered development of HPGs demonstrated in newly emerged bees chronically exposed to imidacloprid (Hatjina et al. 2013; Heylen et al. 2011; Smodiš Škerl and Gregorc 2010).

Although several studies evaluated the effect of single risk factors on HPG development (e.g. Babendreier et al. 2005; Hatjina et al. 2013; Heylen et al. 2011; Smodiš Škerl and Gregorc 2010), little is known about combination of stressors, which can occur in a field-realistic scenario. Here, we tested the hypothesis that low protein content in pollen combined with pesticide exposure has a significant impact on young-bee development. This parameter was directly assessed by measuring the diameter of gland acini and indirectly estimated by measuring the total protein content in bee heads, as an additional indicator of proper functioning of HPGs (Fortini et al. 2009). We used two pollen diets, different in botanical origin and protein content, combined with chronic exposure at two concentrations of thiamethoxam via sucrose solution. Thiamethoxam is a neonicotinoid insecticide, characterised by a high acute toxicity to honeybees (oral $\mathrm{LD}_{50} 5 \mathrm{ng} / \mathrm{bee}$, EFSA 2013) and capable of causing detrimental effects also at sublethal doses. This scenario is likely to occur as honeybees can be exposed to residues of thiamethoxam in fresh pollen (Dively and Kamel 2012; Pilling et al. 2013) and bee bread (Mullin et al. 2010). The effects provoked by the ingestion of sublethal concentrations of this insecticide may entail the impairment of orientation capacities (Henry et al.; 2012), olfactory learning (Aliouane et al. 2009) and queen quality (Williams et al. 2015).

\section{MATERIALS AND METHODS}

\subsection{Rearing conditions and modalities of treatment}

In order to obtain age-matched bees (Apis mellifera ligustica), frames of brood comb containing last-stage pupae were removed from a healthy hive and kept in an incubator under controlled conditions $\left(33 \pm 1{ }^{\circ} \mathrm{C}, 50\right.$ $70 \%$ relative humidity, darkness) until bee emergence. Honeybees, aged from 0 to $24 \mathrm{~h}$, were collected and held in groups of 20 individuals in disposable cardboard cages $(9.5 \times 6.5 \times 5 \mathrm{~cm})$, randomly assigned to the different treatment groups. Five cages per treatment were used.

Each cage was equipped with three syringes of $2.5 \mathrm{~mL}$ adapted as feeders to provide water, sucrose solution $(50 \% \mathrm{w} / \mathrm{w})$ contaminated or not with thiamethoxam and the pollen diet obtained by smashing pollen granules. During the experiment, bees were maintained at controlled conditions $\left(30 \pm 1{ }^{\circ} \mathrm{C}, 50-70 \%\right.$ relative humidity, darkness) and all food was provided ad libitum. Thiamethoxam (analytical grade, Ehrenstorfer, purity $98 \%$ ) was tested at two concentrations, 10 and $40 \mu \mathrm{g} / \mathrm{L}$, with a control group fed with pesticide-free syrup. A stock solution of thiamethoxam was previously prepared in acetone, aliquoted and conserved at $-20^{\circ} \mathrm{C}$. The exact concentration (101 ppm) was checked with LC-MS/MS. The feeding solutions were freshly prepared every 2-3 days, starting from the stock solution, in order to assure a continuous syrup supply.

Two different pollen diets were tested: one containing higher levels of crude protein and wider pollen diversity (hereafter referred to as "High"-quality diet) and the other one with a lower protein content and pollen diversity (hereafter referred to as "Low"-quality diet). Their specific composition and nutritional factors are further described below.

On the 8th and 12th days from the beginning of the experiment, the surviving bees were collected and frozen $\left(-24{ }^{\circ} \mathrm{C}\right)$ to discern the influence of pollen diet composition and concentration of thiamethoxam on bee nurse physiology, specifically on the HPG development and total protein content in the head.

\subsection{Pollen diet analysis}

The pollen granules were obtained from two different apiaries placed in the countryside of Bologna (Northern Italy), collected in pollen traps and visually 
classified depending on the colour of pollen granules. Preliminarily, the samples of monocoloured granules were identified as "Low"-quality pollen, whereas the samples with multicoloured granules were identified as "High"-quality pollen. Subsequently, a palynological analysis under a microscope was used to analyse the composition of both diets, "High" and "Low". The diversity of pollen botanical origin between the diets was then evaluated by means of Simpson's reciprocal index (Magurran 1988). Furthermore, each diet was analysed to determine the nitrogen content $(\mathrm{N})$ as a measure of the level of protein. The nitrogen content was assessed through the Kjeldhal (1883) method and crude protein content was calculated as total $\mathrm{N} \times 6.25$. A multiresidue analysis of 243 compounds was performed using gas and liquid chromatography coupled to mass spectrometry (GC-MS/MS, LC-MS/MS, LOD 0.005$0.01 \mathrm{mg} / \mathrm{kg}$, depending on the a.i.), in order to exclude previous contamination of the pollen diets.

\subsection{Syrup consumption and total pesticide exposure}

The quantity consumed was determined every 23 days, before each refilling, by comparison of the weight of the syrup remaining in the feeders with the initial weight of the full feeder. The difference in milligrams was converted to microlitres $(1 \mu \mathrm{L}=1.22 \mathrm{mg}$ of syrup) and divided by the number of surviving bees. The total amount of pesticide consumed (in ng of thiamethoxam per bee) was calculated after 8 and 12 days of chronic exposure.

\subsection{Measurement of the development of hypopharyngeal glands}

Live bees were sampled 8 and 12 days after the beginning of the experiment and preserved at $-24{ }^{\circ} \mathrm{C}$ for the measurement of the HPG acini. On the 8th day, all the surviving bees from two out of the five initial replicates were taken and used for this purpose. On the 12th day, all the surviving bees from all the replicates were collected. Ten randomly chosen bees per treatment and sampling period were used for HPG measurement; therefore, a total of 120 bees were dissected. Overall, 862 acini were measured, considering an average of 72 acini per treatment per day.

The hypopharyngeal glands were extracted from honeybee heads in physiological solution and under a stereomicroscope in order to isolate the acini. The glands were cleaned from muscles and aerial sacks and afterwards coloured. Methyl blue dissolved in physiological Ringer's solution $(\mathrm{NaCl} 9 \mathrm{~g}, \mathrm{KCl} 0.2$ g, $\mathrm{NaHCO}_{3} 0.2 \mathrm{~g}, \mathrm{CaCl}_{2} 0.2 \mathrm{~g}$ in $1 \mathrm{~L}$ of distilled water) was used as a colourant. Once dyed, the HPGs were transferred to a glass slide with a concave basin filled with physiologic solution and covered with a cover slip (the presence of a concavity is necessary in order to avoid smashing up the glands with the cover slip). The diameter of those acini that were in horizontal position was measured with a Carl Zeiss Axioskop light microscope equipped with an Axiocam digital camera, using AxioVision 4.8 software.

\subsection{Measurement of total protein in the bee head}

In order to measure the protein content, frozen bee heads were homogenised with a pestle at $4{ }^{\circ} \mathrm{C}$ in an extraction medium prepared with $10 \mathrm{mM} \mathrm{NaCl}, 1 \%(w /$ v) Triton $\mathrm{X}-100$ and $40 \mathrm{mM}$ sodium phosphate ( $\mathrm{pH} 7.4)$. As protease inhibitors, $2 \mu \mathrm{g} / \mathrm{mL}$ antipain, leupeptin and pepstatin A; 25 units/ml aprotinin; and $0.1 \mathrm{mg} / \mathrm{mL}$ Lima bean trypsin inhibitor were added (Belzunces et al. 1990). Tissue extracts were centrifuged at $4{ }^{\circ} \mathrm{C}$ for $20 \mathrm{~min}$ at $15,000 \mathrm{~g}$ and the resulting supernatants were collected. For each treatment group, four extracts of four bee heads each (i.e. 16 bees per treatment) were achieved and assayed in triplicate. The protein content was determined in microplates, with a reaction medium containing $10 \mu \mathrm{L}$ of the extract previously diluted $1 / 20,45 \mu \mathrm{L}$ of distilled water and $200 \mu \mathrm{L}$ of Bradford reagent. The absorbance was detected at $595 \mathrm{~nm}$ through a Spectra Max 340 PC by Molecular Devices.

\subsection{Statistical analysis}

The effect of treatments (diet quality and pesticide concentration) on bee mortality, HPG acini size, syrup consumption and total protein content in bee heads was evaluated using two-way ANOVA. The test was performed separately for the 8th and 12th days. Moreover, in order to address normality and homoscedasticity, the percent of bee mortalities and the acini diameter values were arcsine-transformed and log-transformed, respectively. The Tukey HSD post hoc test was used to compare different treatment groups. Statistical analyses 
were performed using R software version 3.0.2 (R Development Core Team 2013).

\section{RESULTS}

\subsection{Pollen diet quality and bee mortality}

The palynological analysis of the pollen granules confirmed that the number of different pollen types in the "High" diet was more than twice higher than that in the "Low" diet (14 vs 6). The "Low" diet consisted mainly of pollen belonging to Graminaceae $(84.14 \%)$ followed by Medicago (12.87\%), Zea (2\%), Helianthus (1\%), Compositae Taraxacum -type $(0.01 \%)$ and Lagerstroemia spp. (0.01\%). The "High" diet showed a larger variety of pollen types, from the following botanic origins: Rubus (60.28\%), Cruciferae (31.15\%), Helianthus $f$. (3.01\%), Papaver (2.01\%), Melilotus (1.51\%), Galega (1\%), Compositae Taraxacum -type (0.5\%), Convolvulus $(0,5 \%)$, Dipsacaceae $(0.01 \%)$, Eucalyptus camaldulensis $(0.01 \%)$, Liriodendron (0.01\%), Lotus (0.01\%), Parthenocissus $(0.01 \%)$ and Rosaceae $(0.01 \%)$. The calculated Simpson biodiversity index for the "High" diet was higher than that for the "Low" diet (2.18 vs 1.38).

In addition to the pollen origin, the protein content was also determined. This analysis confirmed that the "High" diet contained more proteins than the "Low" diet, with 25.2 and $16.5 \%$ of crude protein, respectively. With regard to the pesticide contamination, the chemical analysis evidenced that both pollen diets did not contain pesticide residues (LOD $0.005-0.01 \mathrm{mg} / \mathrm{kg}$, depending on the a.i.).

The average mortality rate after 12 days of the test was $12.1 \%$ and there were no differences across treatments (diet quality: $F_{1,2}=0.01$, $P=0.92$; pesticide concentration: $F_{1,2}=0.08$, $P=0.92$; interaction: $F_{2,2}=0.71, P=0.51$ ), thereby confirming that the tested concentrations (10 and $40 \mu \mathrm{g} / \mathrm{L}$ ) were indeed sublethal.

\subsection{Syrup consumption and total pesticide exposure}

After 8 days of exposure, the average amount of syrup consumed by bees was influenced neither by the diet quality $\left(F_{1,24}=0.39, P=0.54\right)$ nor by the interaction between the diet quality and pesticide concentration $\left(F_{2,24}=1.45, P=0.25\right)$. However, the syrup consumption per honeybee per day significantly increased with the thiamethoxam concentration $\left(F_{2,24}=10.52, P<0.001\right)$. This effect was particularly evident for bees fed with low-quality pollen, which exhibited a significantly higher consumption of syrup contaminated with $40 \mu \mathrm{g} / \mathrm{L}$ compared to pesticide-free syrup (Figure 1a).

From the 9th to the 12th day of exposure, the diet quality did not affect the daily syrup consumption $\left(F_{1,12}=1.67, P=0.22\right)$ and there was no significant interaction between diet quality and pesticide exposure $\left(F_{2,12}=3.40, P=0.068\right)$. The syrup consumption was again influenced by pesticide concentration $\left(F_{2,12}=14.51, P<0.001\right)$ even though in this case honeybees fed with $40 \mu \mathrm{g} / \mathrm{L}$ consumed significantly less syrup than those fed with 10 and $0 \mu \mathrm{g} / \mathrm{L}$ of thiamethoxam, for both pollen diets (Online Resource Table S1, Figure 1b).

Overall, the total amount of pesticide consumed by each bee fed with 10 and $40 \mu \mathrm{g} / \mathrm{L}$ of thiamethoxam during 8 days of exposure was 3.6 and $16.1 \mathrm{ng}$, respectively. After 12 days, the amount of pesticide consumed was 5.8 and $23.7 \mathrm{ng}$ for each bee fed with 10 and $40 \mu \mathrm{g} / \mathrm{L}$ of thiamethoxam, respectively.

\subsection{Development of the hypopharyngeal glands}

The analysis of the overall data with ANOVA showed that the HPG acini diameter measured at day 8 was significantly influenced by the type of diet and more markedly by the pesticide concentration $\left(F_{1,54}=5.98, P=0.018\right.$ and $F_{2,54}=22.36, P<0.001$, respectively), but the effect of the interaction between these factors was not significant $\left(F_{2,54}=0.46, P=0.63\right)$. On average, the acini were $11.5 \%$ larger in bees fed with high-quality diet than in those fed with lowquality diet and showed reduced size with increasing pesticide concentrations (Online Resource Table S2, Figure 2a). The pairwise comparison between treatment groups revealed that, on the 8th day, bees fed with $40 \mu \mathrm{g} / \mathrm{L}$ of thiamethoxam 

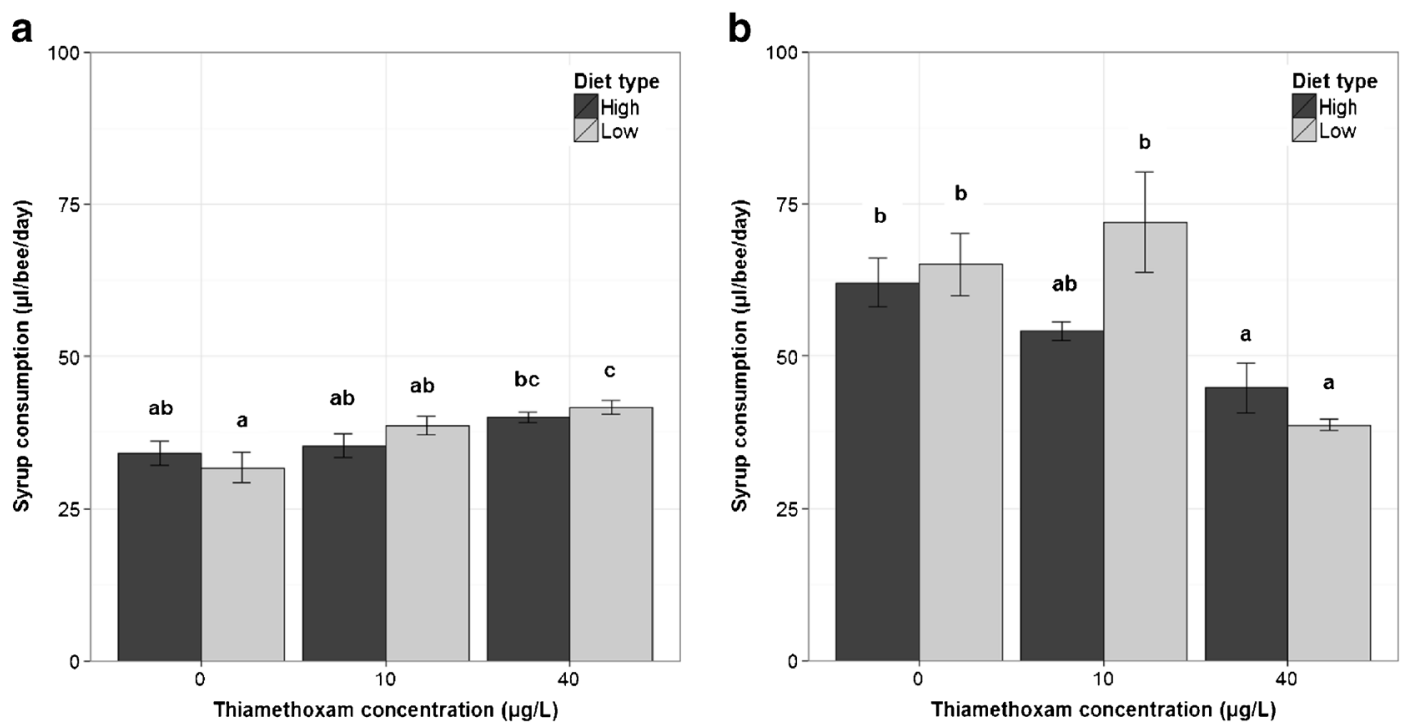

Figure 1. Daily syrup consumption per bee at the 8th (a) and 12th (b) days (mean $\pm \mathrm{SE}$ ) for different thiamethoxam concentrations $(0,10$ and $40 \mu \mathrm{g} / \mathrm{L})$ and pollen diets (high quality and low quality). Different letters indicate Tukey HSD $P<0.05$.

developed significantly smaller acini compared with bees fed with a pesticide-free syrup, regardless of the diet type (Figure 2a). Similarly, on the 12th day, the pesticide concentration had an effect on the acini size $\left(F_{2,54}=5.25, P=0.008\right)$. In fact, the acini of bees exposed to 10 and $40 \mu \mathrm{g} / \mathrm{L}$ of thiamethoxam were smaller than those of control bees (reduction of 7.5 and $13.2 \%$, respectively) (Table S2). This was particularly evident comparing bees fed with the high-quality pollen diet
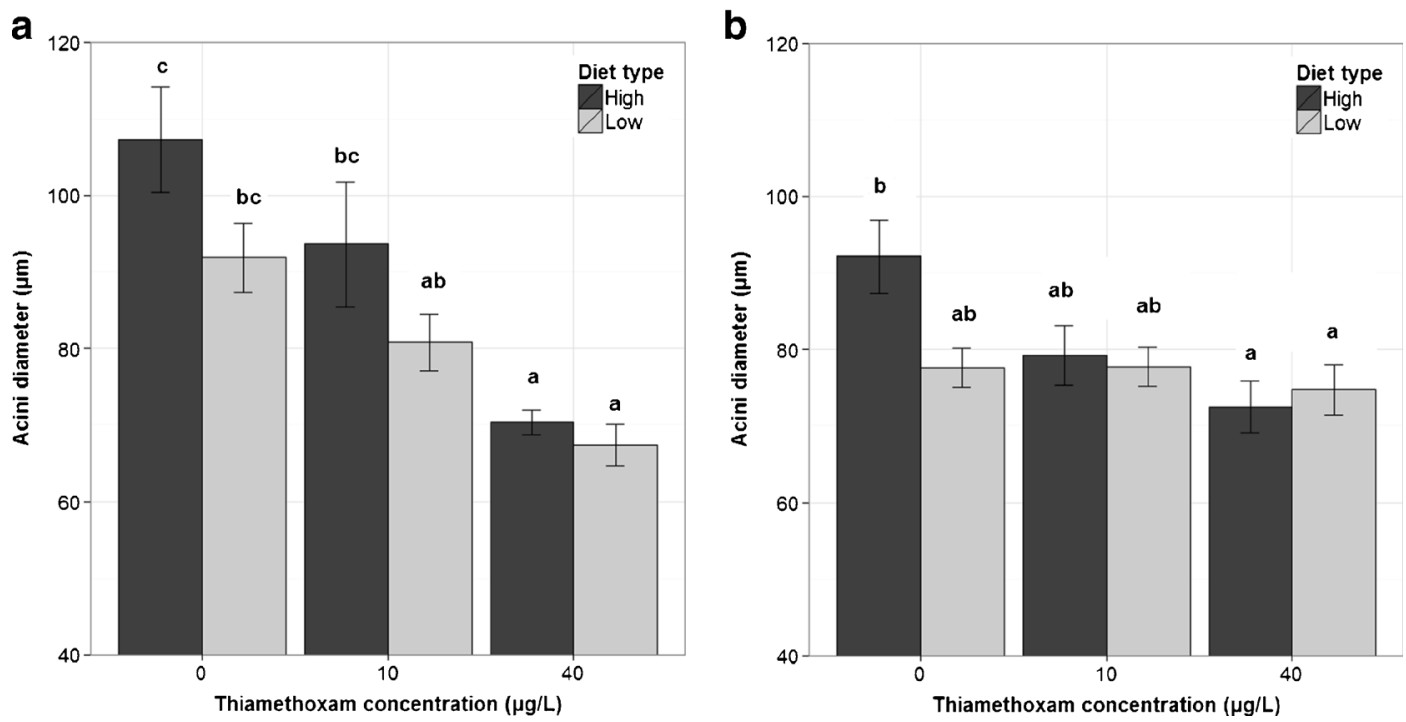

Figure 2. Diameter of the hypopharyngeal gland acini on the 8th (a) and 12th (b) days (mean \pm SE) for different thiamethoxam concentrations $(0,10$ and $40 \mu \mathrm{g} / \mathrm{L}$ ) and pollen diets (high quality and low quality). Different letters indicate Tukey HSD $P<0.05$. 
combined or not with contaminated syrup at $40 \mu \mathrm{g} / \mathrm{L}$ (Figure 2b). However, ANOVA did not reveal any significant difference between the "High" and the "Low" diet, considering the overall data $\left(F_{1,54}=1.99, P=0.164\right)$. The interaction between factors $\left(F_{2,54}=2.89, P=0.064\right)$ had no significant effect.

A variation of the HPG development was also observed in terms of general aspect of the acini. Usually, the acini appeared with a regular shape and a smooth outline (Figure $3 \mathrm{a}, \mathrm{b}$ ), but some of the dissected bees presented more irregularly shaped acini, with a wrinkled or crumpled outline (Figure 3e, f). Overall, the observations of these "degenerating" acini occurred more frequently in bees fed with the "Low" diet and contaminated syrup.

\subsection{Total protein in the bee head}

After 8 days, the protein content in bee heads was significantly affected by the pesticide treatment $\left(F_{2,63}=4.52, P=0.015\right)$, but not by pollen quality $\left(F_{1,63}=0.19, P=0.66\right)$. However, the effect of the interaction between the diet quality and the thiamethoxam exposure was significant $\left(F_{2,63}=7.12, P=0.002\right)$. In fact, we observed that the protein content in bee heads decreased with increasing concentrations of thiamethoxam in bees fed with the high-quality diet, but not in bees fed with low-quality pollen (Figure 4a). At day 12 , feeding with thiamethoxam reduced the protein content in the bee heads $\left(F_{2,66}=11.56\right.$, $P<0.001$ ), particularly at $40 \mu \mathrm{g} / \mathrm{L}$ (Online Resource Table S3, Figure 4b). On the contrary, the protein content was influenced neither by the diet quality $\left(F_{1,66}=1.02, P=0.31\right)$ nor by its interaction with the pesticide treatment $\left(F_{2,66}=1.06\right.$, $P=0.351$ ) (Figure 4b).

\section{DISCUSSION}

This study confirms the importance of the food quality (Brodschneider and Crailsheim 2010), considered as nutritional value and pesticide contamination, for the physiological development of honeybees, which could be evaluated through the assessment of the morphology of HPGs in young bees.
In order to assess the effect of the pollen nutritional value on HPGs, we used two types of curbicular pollen from different apiaries to reproduce a realistic diet composition, with a varied presence of pollen from different plants and quantity of total protein content. The protein content of the pollen diets used in our experiment (16.5 and $25.2 \%$ of proteins in the "Low" and "High" diets, respectively) can be considered representative of different nutritional scenarios, and is similar to nutritional reference values used in other studies (Di Pasquale et al. 2013; Pernal and Currie 2000; Standifer et al. 1970). Our results confirm the positive effect of a high-protein diet on HPG size for bees sampled the 8th day, which corresponds to the age of maximum development of HPGs in worker bees (Al-Ghamdi et al. 2011; Lass and Crailsheim 1996). On the 12th day, bees showed smaller acini than bees sampled at day 8 , confirming the age-dependent development of HPGs, with acini that reach the maximum size around 6-8 days, in correspondence to the nursing task carried out in the hive (Deseyn and Billen 2005; Rahman et al. 2014). The decrease in acini size observed in 12-day-old bees was no longer influenced by the diet quality. This could be ascribed to the premature decrease in size of HPG acini that might occur in caged bees, as described by Lass and Crailsheim (1996), regardless of the pollen diet quality, which is probably due to the lack of brood in artificial rearing conditions (DeGrandi-Hoffman et al. 2010).

The HPG development was also observed in relation to the administration of two realistic concentrations of thiamethoxam. In fact, it has been demonstrated that plants treated with thiamethoxam can have residues in fresh pollen ranging from 68 to 95.2 ppb (Dively and Kamel 2012). Moreover, several survey studies have detected residues of thiamethoxam ranging from 7.4 to $98 \mathrm{ppb}$ in pollen loads (Krupke et al. 2012; Lambert et al. 2013) and in bee bread (Mullin et al. 2010).

With the present study, we demonstrated that a 12-day chronic exposure to field-relevant concentrations of thiamethoxam can affect HPG development, resulting in smaller acini and in frequent modification of their shape. While the pollen type caused a significant reduction of acini size at day 8 but not at day 12 , the treatment with 

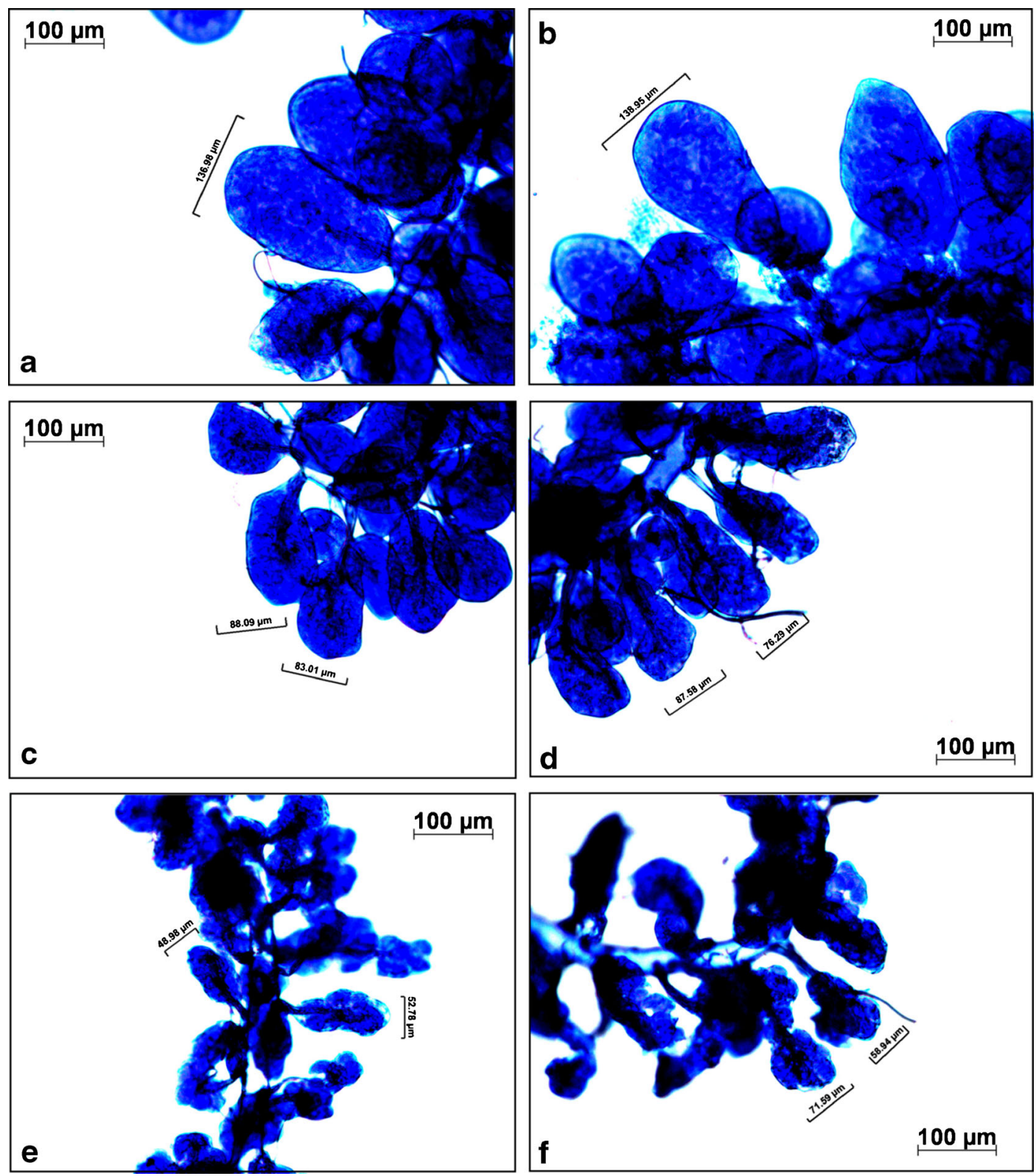

Figure 3. Different shapes of HPG acini observed. As the pesticide concentration increased and the diet quality decreased, the acini had a reduced size and acquired a more irregular outline, and the general aspect of the HPGs became less compact. a, b "High" and "Low" diet combined with $0 \mu \mathrm{g} / \mathrm{L}$ of thiamethoxam; c, d "High" and "Low" diet combined with $10 \mu \mathrm{g} / \mathrm{L}$ of thiamethoxam; and e, f "High" and "Low" diet combined with $40 \mu \mathrm{g} / \mathrm{L}$ of thiamethoxam.

thiamethoxam appeared to be a stronger stressor, since it had a significant impact in bees exposed for both 8 and 12 days. A similar reduction of acini size has been demonstrated for sublethal dietary concentrations of another neonicotinoid insecticide, imidacloprid, administered chronically both for 24-72 h (Smodiš Škerl and Gregorc 2010) and for a longer period of 14 days (Hatjina 
a

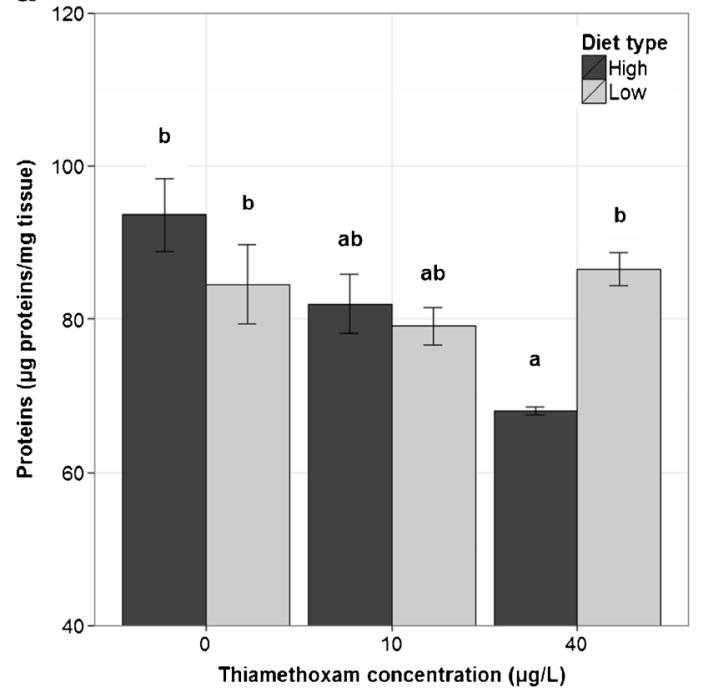

b

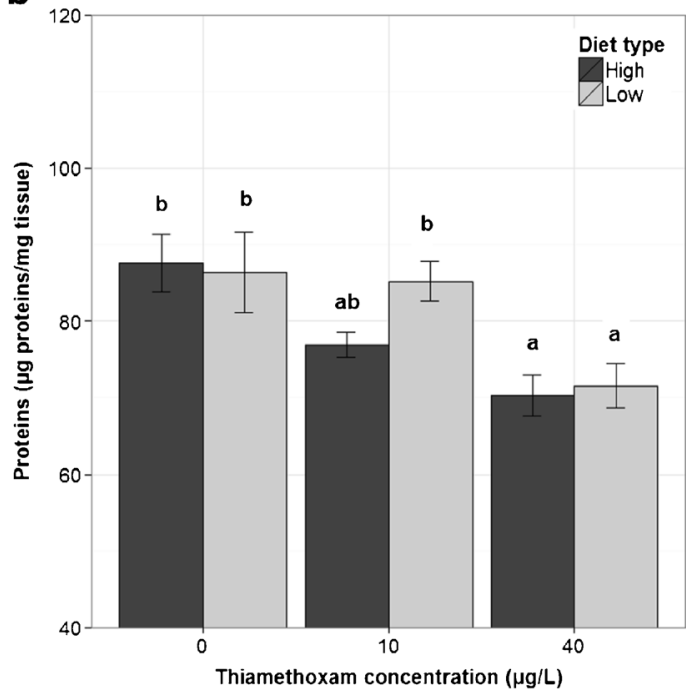

Figure 4. Protein concentration in the head at the 8th (a) and 12th (b) days (mean \pm SE) for different thiamethoxam concentrations $(0,10$ and $40 \mu \mathrm{g} / \mathrm{L})$ and pollen diets (high quality and low quality). Different letters indicate Tukey HSD $P<0.05$.

et al. 2013). Moreover, in our experiment, the thiamethoxam effect was dependent on the administered concentration, as the bees receiving $40 \mu \mathrm{g} /$ $\mathrm{L}$ ad libitum exhibited a reduced diameter of HPG acini compared to the bees fed with $10 \mu \mathrm{g} / \mathrm{L}$. It is to be noted that the total bee exposure was influenced not only by the pesticide concentration in the diet but also by the diet consumption rate. In fact, the syrup contaminated with the highest pesticide concentration was consumed significantly more than the other diets, particularly within the first 8 days of the experiment. This phenomenon could have led to the even higher exposure of the treated bees.

Bees treated with the highest concentration of thiamethoxam, regardless of the diet type, exhibited frequent malformations of the acini shape, also observed by Heylen et al. (2011) in bees treated with fenoxycarb. Smodiš Škerl and Gregorc (2010) evidenced a role of programmed cell death and cell necrosis in HPGs perturbed by a chemical stressor, which could explain the premature degradations of acini observed in our experiment.

The effect of the pollen type and the pesticide exposure on the total protein content in bee heads was also assessed, as it can be considered as a complementary method to investigate the impact of stressors on the functionality of HPGs (DeGrandi-Hoffman et al. 2010; Fortini et al. 2009). The protein biosynthesis in HPGs is likely to have two phases during a bee life, accounting for royal jelly protein production during the nursing period and shifting to the secretion of other molecules and enzymes, such as glucose oxidase, later in time (Kubo et al. 1996).

Therefore, the protein concentration in young bees might underlie differences in nursing capacity. To this extent, the measurement of the protein content of dissected HPGs would be a more specific but time-consuming method that could be effectively replaced by the estimation of the total protein content in bee heads (Fortini et al. 2009). In our experiment, the head protein content was not significantly different for bees fed with highand low-quality diets, in both sampling dates, which coincides with the results obtained from acini size measurement only at day 12 . The chronic exposure to thiamethoxam determined a general decrease in head proteins, which was consistent with the variations in acini size, even though at day 8 the protein concentration did not adequately reflect the dose-dependent effect which was observed for HPG acini. As evidenced by Rahman et al. (2014), the protein concentration may not 
always be correlated with the HPG size, probably because of the above-mentioned differential pattern of protein expression over the life of a bee. To that purpose, it might be also interesting to evaluate the changes in bee head protein composition in response to different stressors. The assessment of HPG acini size seemed to be more sensitive than protein quantification in order to estimate the impact of pesticide contamination and pollen quality on the development of young bees. Nevertheless, it must be stressed that the protein assessment with standardised methods is less influenced by evaluation bias than the visual assessment of acini size (e.g. choice of acini, ability to extract and measure them). Thus, an international ring test would be recommended to compare the suitability of both methodologies for pesticide risk assessment to bees. To this extent, since pollen type showed a significant effect on HPG development, we suggest that the diet composition should be considered as a standardised parameter in such experimentation.

\section{ACKNOWLEDGMENTS}

We thank Grillenzoni F.V. and Corvucci F. for palynological analysis, and Colombo R., Serra G. and Boi M. for chemical analysis. We also thank Bergamini D. for practical support in the experimentations. We very much appreciate the constructive and helpful comments of two anonymous reviewers.

\section{COMPLIANCE WITH ETHICAL STANDARDS}

Conflict of interest The authors declare that they have no conflict of interests.

Effet combiné -qualité du pollen et thiametoxane- sur le développement des glandes hypopharyngiennes et sur la teneur en protéines chez Apis mellifera

abeille / glande hypopharyngienne / néonicotinoïdes / alimentation en pollen / toxicité chronique

Kombinierte Effekte der Pollenqualität und von Thiamethoxam auf die Entwicklung der Hypopharynxdrüsen und deren Proteingehalt bei Apis mellifera
HPGs / Honigbiene / Neonikotinoid / Pollendiät / chronische Toxizität

\section{REFERENCES}

Al-Ghamdi, A.A., Al-Khaibari, A.M., Omar, M.O.M. (2011) Effect of honeybee race and worker age on development and histological structure of hypopharyngeal glands of honeybee. Saudi J. Biol. Sci. 18(2), 113-116

Aliouane, Y., El Hassani, A.K., Gary, V., Armengaud, C., Lambin, M., et al. (2009) Subchronic exposure of honeybees to sublethal doses of pesticides: effects on behavior. Environ. Toxicol. Chem. 28, 113-122

Auclair, J.L., Jamieson, C.A. (1948) A qualitative analysis of amino acids in pollen collected by bees. Science 108, 357-358

Babendreier, D., Kalberer, N.M., Romeis, J., Fluri, P., Mulligan, E., et al. (2005) Influence of Bt-transgenic pollen, Bt-toxin and protease inhibitor (SBTI) ingestion on development of the hypopharyngeal glands in honeybees. Apidologie 36 (4), 585-594

Belzunces, L.P., Theveniau, M., Masson, P., Bounias, M. (1990) Membrane acetylcholinesterase from Apis mellifera head solubilized by phosphatidylinositol-specific phospholipase $\mathrm{C}$ interacts with an anti-CRD antibody. Comp. Biochem. Phys. B 95, 609-612

Brodschneider, R., Moosbeckhofer, R., Crailsheim, K. (2010) Surveys as a tool to record winter losses of honey bee colonies: a two year case study in Austria and South Tyrol. J. Apic. Res. 49 (1), 23-30

Crailsheim, K. (1992) The flow of jelly within a honeybee colony. J. Comp. Physiol. B 162 (8), 681-689

DeGrandi-Hoffman, G., Wardell, G., Ahumada-Segura, F., Rinderer, T., Danka, R., et al. (2008) Comparisons of pollen substitute diets for honey bees: consumption rates by colonies and effects on brood and adult populations. J. Apic. Res. 47 (4), 265-270

DeGrandi-Hoffman, G., Chen, Y.P., Huang, E., Huang, M.H. (2010) The effect of diet on protein concentration, hypopharyngeal gland development and virus load in worker honey bees (Apis mellifera L.). J. Insect Physiol 56(9), 1184-1191

Deseyn, J., Billen, J. (2005) Age-dependent morphology and ultrastructure of the hypopharyngeal gland of Apis mellifera workers (Hymenoptera, Apidae). Apidologie 36 (1), 49-57

Di Pasquale, G., Salignon, M., Le Conte, Y., Belzunces, L.P., Decourtye, A., et al. (2013) Influence of pollen nutrition on honey bee health: do pollen quality and diversity matter? PLoS ONE 8 (8), e 72016

Dively, G.P., Kamel, A. (2012) Insecticide residues in pollen and nectar of a cucurbit crop and their potential exposure to pollinators. J. Agric. Food Chem. 60 (18), 4449-4456 
European Food Safety Authority (2013) Conclusion on the peer review of the pesticide risk assessment for bees for the active substance thiamethoxam. EFSA Journal 11, 3067 [68 pp.]

Fortini, D., Michaud, B., Aupinel, P. (2009) Comparison of two methods to assess effects of insecticides on hypopharyngeal gland development of honey bee. Hazards of pesticides to bees - 10 th International Symposium of the ICP-Bee Protection Group

Hatjina, F., Papaefthimiou, C., Charistos, L., Dogaroglu, T., Bouga, M., et al. (2013) Sublethal doses of imidacloprid decreased size of hypopharyngeal glands and respiratory rhythm of honeybees in vivo. Apidologie 44 (4), 467-480

Haydak, M.H. (1970) Honey bee nutrition. Annu. Rev. Entomol. 15, 143-156

Henry, M., Béguin, M., Requier, F., Rollin, O., Odoux, J.F., et al. (2012) A common pesticide decreases foraging success and survival in honey bees. Science $\mathbf{3 3 6}$, 348-350

Herbert, E.W., Shimanuki, H., Caron, D. (1977) Optimum protein levels required by honey bees (Hymenoptera: Apidae) to initiate and maintain brood rearing. Apidologie 8, 141-146

Heylen, K., Gobin, B., Arckens, L., Huybrechts, R., Billen, J. (2011) The effects of four crop protection products on the morphology and ultrastructure of the hypopharyngeal gland of the European honeybee, Apis mellifera. Apidologie 42 (1), 103-116

Khoury, D.S., Myerscough, M.R., Barron, A.B. (2011) A quantitative model of honey bee colony population dynamics. PLoS ONE 6 (4), e18491

Kjeldhal, J. (1883) Neue Methode zur Bestimmung des Stickstoffs in organischen Körpern. Z. Anal. Chem. 22, 366-382

Krupke, C.H., Hunt, G.J., Eitzer, B.D., Andino, G., Given, K. (2012) Multiple routes of pesticide exposure for honey bees living near agricultural fields. PLoS ONE 7 (1), e29268

Kubo, T., Sasaki, M., Nakamura, J., Sasagawa, H., Ohashi, K., et al. (1996) Change in the expression of hypopharyngeal-gland proteins of the worker honeybees (Apis mellifera L) with age and/or role. J. Biochem. 119 (2), 291-295

Lambert, O., Piroux, M., Puyo, S., Thorin, C., L'Hostis, M., et al. (2013) Widespread occurrence of chemical residues in beehive matrices from apiaries located in different landscapes of western France. PLoS ONE 8(6), e67007

Lass, A., Crailsheim, K. (1996) Influence of age and caging upon protein metabolism, hypopharyngeal glands and trophallactic behavior in the honey bee (Apis mellifera L). Insectes Soc. 43 (4), 347-358
Magurran, A.E. (1988) Ecological diversity and its measurement. Chapman and Hall, London

Mullin, C.A., Frazier, M., Frazier, J.L., Ashcraft, S., Simonds, R., et al. (2010) High levels of miticides and agrochemicals in North American apiaries: implications for honey bee health. PLoS ONE 5 (3), e9754

Naug, D. (2009) Nutritional stress due to habitat loss may explain recent honeybee colony collapses. Biol. Conserv. 142 (10), 2369-2372

Pernal, S.F., Currie, R.W. (2000) Pollen quality of fresh and 1-year-old single pollen diets for worker honey bees (Apis mellifera L.). Apidologie 31 (3), 387-409

Pilling, E., Campbell, P., Coulson, M., Ruddle, N., Tornier, I. (2013) A four-year field program investigating longterm effects of repeated exposure of honey bee colonies to flowering crops treated with thiamethoxam. PLoS ONE 8 (10), e 77193

R Development Core Team (2013) R: A language and environment for statistical computing. R Foundation for Statistical Computing, Vienna, Austria

Rahman, S., Thangkhiew, I., Hajong, S.R. (2014) Hypopharyngeal gland activity in task-specific workers under brood and broodless conditions in Apis cerana indica (Fab.). J. Apic. Sci. 58, 61-70

Rortais, A., Arnold, G., Halm, M.-P., Touffet-Briens, F. (2005) Modes of honeybees exposure to systemic insecticides: estimated amounts of contaminated pollen and nectar consumed by different categories of bees. Apidologie 36, 71-83

Roulston, T.H., Cane, J.H. (2000) Pollen nutritional content and digestibility for animals. Plant Syst. Evol. 222, 187-209

Sagili, R.R., Pankiw, T. (2007) Effects of proteinconstrained brood food on honey bee (Apis mellifera L.) pollen foraging and colony growth. Behav. Ecol. Sociobiol 61 (9), 1471-1478

Schmidt, J.O., Thoenes, S.C., Levin, M.D. (1987) Survival of honey bees, Apis mellifera (Hymenoptera: Apidae), fed various pollen sources. Ann. Entomol. Soc. Am. 80, 176-183

Smodiš Škerl, M.I., Gregorc, A. (2010) Heat shock proteins and cell death in situ localisation in hypopharyngeal glands of honey bee (Apis mellifera carnica) workers after imidacloprid or coumaphos treatment. Apidologie 41, 73-86

Standifer, L.N., Macdonald, R.H., Levin, M.D. (1970) Influence of the quality of protein in pollens and of a pollen substitute on the development of the hypopharyngeal glands of honey bees. Ann. Entomol. Soc. Am. 63, 909-910

Williams, G.R., Troxler, A., Retschnig, G., Roth, K., Yañez, O., et al. (2015) Neonicotinoid pesticides severely affect honey bee queens. Sci. Rep. 5, 14621 